\title{
Fouling of a heat exchange surface by whey, milk and model fluids. An analytical study
}

\author{
G. DAUFIN *, J.P. LABBÉ **, A. QUEMERAIS ***, G. BRULÉ *, \\ Françoise $\mathrm{MICHEL}^{*}, \mathrm{M}$. ROIGNANT ${ }^{*}$ and M. PRIOL *** \\ * INRA, Laboratoire de Recherches de Technologie laitière, \\ 65, rue de Saint-Brieuc, 35042 Rennes Cedex, France \\ ** Ecole Nationale Supérieure de Chimie, Laboratoire de Corrosion, \\ 11 rue P.-et-M.-Curie, 75231 Paris Cedex, France \\ Université Rennes I, Faculté des Sciences, Laboratoire de Spectroscopie du Solide, U.A. \\ C.N.R.S. 1202, avenue du $G^{a l}$-Leclerc, Campus de Beaulieu, 35042 Rennes Cedex, France
}

\section{Summary}

Fouling caused by sweet whey, milk, artificial ultrafiltrate, phosphate and calcium solution and protein solutions was studied in well defined hydrodynamic (flow rate : $0.096 \mathrm{~m} . \mathrm{s}^{-1}$ ) and thermal conditions (temperatures ranging from 25 to $88^{\circ} \mathrm{C}$ with a standard value of $72{ }^{\circ} \mathrm{C}$; temperature difference with the heat carrier fluid : 0,5 or $10{ }^{\circ} \mathrm{C}$ ) using a laboratory fouling device. Deposits were assessed quantitatively by weighing and qualitatively by Auger electron spectrocopy, X photoelectron spectroscopy and infrared spectroscopy. These spectra gave evidence for three main groups of compounds: proteins, phosphates and lipids as well as the corresponding atoms (calcium, phosphorus, nitrogen and carbon). These findings suggest a fouling mechanism based on calcium phosphate building-up, with various structures ranging from simple well crystallized phases ( phosphate + calcium » solution) to much more complex phases including carboxylate groups; the latter are present in substances as different as citrate (artificial ultrafiltrate and whey) or proteins (soluble or caseins). In the case of milk and whey, proteins participate in the formation of the first fouling layers. Thus, the best way of preventing fouling seems to be the inhibition of calcium phosphate formation.

Key words : Fouling - Milk - Whey - Infrared and electron spectrometry.

\section{Résumé}

Encrassement d'une surface d'échange de chaleur par du lactosérum, du lait et des fluides modèles. Etude analytique

Cette étude de l'encrassement a été menée sur de l'acier inoxydable $304 \mathrm{~L}$ à l'état poli en contact avec du lait, du lactosérum doux, de l'ultrafiltrat synthétique, une solution de phosphate et calcium et des solutions de protéines dans des conditions thermiques et hydrodynamiques bien définies grâce à une plate-forme d'encrassement de laboratoire. Dans une première étape, nous avons fait varier la température lors de 
l'encrassement par du lactosérum doux, considéré comme modèle de la fraction non caséinique du lait, mais aussi comme fluide industriel à pouvoir encrassant élevé. Dans la seconde, nous avons réalisé des cinétiques d'encrassement par des fluides plus simples modélisant les fractions minérale et protéique du lactosérum et du lait.

Des analyses par spectrométrie d'électrons Auger et photoémission excitée par rayons $X$ (SPX) ont été effectuées sur des films minces ou épais dont la masse était évaluée par pesée. En spectrométrie Infra Rouge, la mesure la plus fiable pour avoir accès à l'absorption vraie (notamment au niveau quantitatif), reste le spectre par transmission. Une technique de microprélèvement et de micropastillage a été mise au point, l'enregistrement se faisant en particulier sur un appareil Brucker (45) à transformée de Fourier. L'interprétation des spectres fait apparaitre trois grands groupes de composés: protéines, lipides, phosphates. Leurs proportions relatives peuvent être mesurées d'après les intensités relatives des bandes correspondantes après étalonnage à l'aide de mélanges préparés par micropesée.

Le résultat le plus fondamental qui ressort des études effectuées avec le lactosérum en fonction de la température $\left(25\right.$ à $\left.88^{\circ} \mathrm{C}\right)$ et de la durée $(1$ à $40 \mathrm{mn})$ est que les protéines sont toujours majoritaires. L'intervention des phosphates fait intervenir deux phénomènes au moins. Leur présence à basse température s'interprète par une interaction complexante avec le calcium et les protéines, la dénaturation thermique de ces dernières ayant pour première conséquence une diminution de la teneur relative en phosphates dans le dépót. Cette interaction est confirmée par la mesure des liaisons carboxylate en fonction de la température. Mais une brusque élévation de la teneur en phosphate de calcium s'observe ensuite à partir de $64{ }^{\circ} \mathrm{C}$. La structure quasi-amorphe du solide formé traduit une forte sursaturation dont l'une des causes est une diminution de l'action complexante des protéines, autorisant une nucléation hétérogène nouvelle à partir des structures protéiques en place ; le phosphate de calcium formé donne alors une meilleure cohésion à un film majoritairement organique. A $88^{\circ} \mathrm{C}$, la diminution de la teneur en phosphates dans le dépôt traduit normalement une nucléation supplémentaire au sein du fluide.

Les mesures faites en utilisant les fluides modèles montrent des encrassements d'autant plus forts (en masse) et peu adhérents que le fluide est plus simple. Simultanément, les phosphates de calcium observés présentent des structures d'autant plus cristallines. Les hydrogénophosphates obtenus avec le fluide "phosphate + calcium" n'ont aucune adhérence et d'ailleurs rien de commun avec les apatites quasi cristallines produites par l'ultrafiltrat synthétique pour lequel les citrates constituent déjà, par leurs fonctions carboxylates, une analogie avec les protéines; l'interaction structurale des citrates avec les phosphates les fait sans doute participer à la nucléation, en surface, d'apatites qui sont très vite majoritaires, surtout en présence d'un gradient de température.

Pour les autres fluides quí contiennent tous des protéines, les phosphates quasiamorphes formés ont un profil de bande original. Enfin, la complexation du calcium par les citrates ne supprime pas totalement les bandes des phosphates. Les cations correspondants peuvent etre $\mathrm{Fe}^{3+}$ (provenant du support) mais aussi $\mathrm{Ca}^{2+}$, ce qui confirmerait une assez forte interaction avec les protéines. Ces dernières, constituants du lactosérum et du lait, sont toujours majoritaires dès les temps courts, accompagnées de lipides dont on ne parvient pas à justifier un róle moteur dans la croissance des dépôts, Concernant les protéines, que nous n'avons pas pu identifier dans le détail, les connaissances recueillies dans la bibliographie permettent d'envisager un rôle privilégié de la $\beta$-lactoglobuline, agrégée aux caséines dans le lait ou séule dans le lactosérum. tant dans l'adsorption des premières couches que dans la croissance ultérieure des dépôts. Cette dernière n'est manifestement possible que si le calcium et le phosphate sont susceptibles de précipiter. Les phases quasi-amorphes formées ont des interactions avec les protéines (et peut être les lipides). Ces interactions pourraient s'effectuer en particulier avec les groupements carboxylates des acides aspartique et glutamique des 
protéines du lactosérum. De même, le groupement phosphate de la phosphosérine des caséines du lait peut être impliqué dans ce type d'interaction complexante.

Ainsi se dégagerait un mécanisme de croissance de l'encrassement qui pourrait s'appliquer à tous les fluides que nous avons étudiés, reposant sur la formation de phosphate de calcium allant de phases simples bien cristallisées à des phases beaucoup plus complexes incluant des carboxylates. Ces derniers groupements jouent le rôle de pôle d'interaction avec des substances comme le citrate ou les protéines (solubles ou caséines). Il se dégage ainsi une idée maîtresse pour lutter contre l'encrassement : inhiber la formation des phosphates de calcium.

Mots clés : Encrassement - Lait - Lactosérum - Spectrométries infrarouge et électronique.

\section{Introduction}

Reviews of the literature by Burton (1968), Lund and Bixby (1975) and more recently LUND and SANDU (1981) show that fouling of heat exchange surfaces has been studied by many research teams the last 25 years, especially in the case of deposit forming substances such as milk and dairy products. The advances obtained through the descriptive approaches by Chemical Engineering and/or Biochemistry have only led to development of empirical fouling models giving a poor information about the mechanisms and the means of prevention.

Since the Symposium on «Fundamentals and applications of surface phenomena associated with fouling and cleaning in food processing » (1981) in Sweden, several small scale-models for studying fouling have been developed (DELSING and HidDINK, 1983 ; Hege, 1984; Tissier et al., 1985) including that of our laboratory (RoIGNANT et al., 1983). The latter has the main characteristics of a good small scale-model (HEGE, 1984) ensuring in particular the control of thermal and hydrodynamic working conditions including preheating of the fluid which plays a major part in fouling.

Milk and whey are often used in research on fouling. The interpretation of results is difficult because of the complexity of the phenomena probably closely related to the heat stability of the products and their components (STIPON, 1983).

Hypotheses concerning the mechanisms of fouling were determined more accurately in recent studies (DELSING and HiddinK, 1983; Hege, 1984 ; LALANDE et al., 1984 a and b). They are different according to the fluids studied (solutions of inorganic ions and milk proteins, whey, milk) and working conditions (previous heat treatments of the product, temperature range). In a recent study on the heat treatment of some dairy products (ROIGNANT et al., 1986) we concluded that whey is a highly foulant fluid of industrial interest and liable to be chosen as a model fluid for the non casein fraction of milk.

All these elements were taken into account to divide this study into two successive phases. In the first one the variations in whey induced fouling vs. temperature were investigated. In the second one fouling kinetics of simpler fluids were studied, using models of whey and milk inorganic and protein 
fractions. The deposits obtained were analysed by Auger electron as well as by $X$ photoelectron and infrared spectroscopy.

The purpose of these tests made in hydrodynamic and thermal conditions simulating a heat exchange was to determine more accurately the nature of the components first adhering to the surface or the first steps of fouling growth at the exchange surface as these phenomena condition the subsequent deposit development.

\section{Materials and methods}

\section{A. Laboratory fouling-model and fouling conditions}

Fouling was obtained using a previously described experimental device (RoIGnANT et al., 1983). The main equipment included a tubular preheater and a small scale heat exchanger with a fouling fluid flow at $0.096 \mathrm{~m} \cdot \mathrm{s}^{-1}$ mean velocity (volumetric flow rate $=10.41 . \mathrm{h}^{-1}$; flow channel thickness $=1.5 \mathrm{~mm}$ ) and a counter-current flow of distilled water at $0.35 \mathrm{~m} \cdot \mathrm{s}^{-1}\left(2501 . \mathrm{h}^{-1}\right)$. In these conditions the residence time of the fluid in the preheater was 28 seconds.

The $304 \mathrm{~L}$ stainless steel surface $\left(8 \mathrm{~cm}^{2}\right.$ working area) was polished with abrasive paper (grain size $80 \mu \mathrm{m}$ ) and left for $24 \mathrm{~h}$ until weighing.

The experiments were performed at the following temperatures : 25,48 , $56,64,72,80,85$ and $88^{\circ} \mathrm{C}$. Along the other side (heat exchange wall thickness : $0.6 \mathrm{~mm}$ ), the distilled water temperature gave known reproducible gradients, the temperature difference being $0,+5$ or $+10^{\circ} \mathrm{C}$. The fouling tests were thus performed in well determined realistic conditions (in comparison with an industrial heat exchanger, RolgnANT, 1987), but our device did not allow problems arising from the degasing and steady flow establishment to be solved.

\section{B. Experimental procedure}

Before each experiment the equipment was cleaned according to the following « dairy cleaning » sequence : $2 \% \mathrm{NaOH}, 65^{\circ} \mathrm{C}, 10 \mathrm{~min}$, then $1.3 \%$ $\mathrm{HNO}_{3}, 70^{\circ} \mathrm{C}, 5 \mathrm{~min}$. A distilled water rinse was applied after each treatment and at the end of the sequence. The exchanger was then brought to hydrodynamic and thermal steady state by means of distilled water for about $10 \mathrm{~min}$.

Thereafter the fouling test was started and lasted 1, 2.5, 5, 10, 20 or 40 min according to cases.

\section{Fluids}

In order to ensure reproducible solutions throughout this study two industrial fluids (milk, whey) were reconstituted from powder at room temperature $\left(20^{\circ} \mathrm{C}\right)$ and model fluids were obtained from chemically pure products (pro analysis quality), supplying solutions with an aqueous phase similar to that of whey and milk. 
Skimmilk $(\mathrm{pH}=6.6)$ was prepared from a «low heat» powder in a proportion of $90.0 \mathrm{~g}$ dry matter per liter of distilled water.

Sweet whey for cooked cheese $(\mathrm{pH}=6.6)$ was reconstituted from distilled water and powder in the proportion of $63.2 \mathrm{~g}$ dry matter per liter.

Whey «with no calcium precipitable» $(\mathrm{pH}$ 6.6) was prepared in two totally different ways :

- a) Complexed calcium whey where soluble calcium was complexed into di-and tri-calcium citrate by adding 2 citrate ions for $1 \mathrm{Ca}^{2+}$. Preparation of the standard citrate solution was made with trisodium citrate $\left(\mathrm{Na}_{3} \mathrm{C}_{6} \mathrm{H}_{5} \mathrm{O}_{7}, 2 \mathrm{H}_{2} \mathrm{O}\right)$ at $110.3 \mathrm{~g} .1^{-1}$. Ten milliliters of this solution were added to $990 \mathrm{ml}$ sweet whey and $\mathrm{pH}$ was adjusted to 6.6 with $4.5 \mathrm{ml} \mathrm{N}-\mathrm{KOH}$.

- b) Whey decalcified by diafiltration. A total of $1.66 \mathrm{I}$ whey was prepared 3 times more concentrated ( $189.6 \mathrm{~g}$ dry matter per liter) than the normal one. Diafiltration (Romicon PM 45 hollow fibre membrane) was performed by 10.91 synthetic ultrafiltrate in which $\mathrm{Ca}$ and $\mathrm{Mg}$ were replaced by $\mathrm{Na}$ so as to keep the ionic strength (around 0.14). Decalcified whey was then reconstituted by adding 3.331 of the same ultrafiltrate without calcium and magnesium. This resulted in a whey containing $2.59 \mathrm{g.} \mathrm{1}^{-1} \beta$-lactoglobulin and $9.6 \mathrm{mg} .1^{-1}$ calcium, but no $\alpha$-lactalbumin.

The synthetic ultrafiltrate was composed of lactose, urea, citrate and inorganic ions. It did not contain any proteins. Four standard solutions were prepared (all figures are in $\mathrm{g} . \mathrm{I}^{-1}$ ) :

$$
\begin{aligned}
\mathrm{A}_{1}: & 87.8 \mathrm{KH}_{2} \mathrm{PO}_{4}+51.8 \mathrm{~K}_{3} \mathrm{C}_{6} \mathrm{H}_{5} \mathrm{O}_{7}, \mathrm{H}_{2} \mathrm{O}+77.8 \mathrm{Na}_{3} \mathrm{C}_{6} \mathrm{H}_{5} \mathrm{O}_{7}, 2 \mathrm{H}_{2} \mathrm{O} \\
& +9 \mathrm{~K}_{2} \mathrm{SO}_{4}+30 \mathrm{KCl}
\end{aligned}
$$

$\mathrm{A}_{2}: 55 \mathrm{CaCl}_{2}+27.2 \mathrm{MgCl}_{2}, 6 \mathrm{H}_{2} \mathrm{O}$

B : $150 \mathrm{C}_{12} \mathrm{H}_{22} \mathrm{O}_{11}, \mathrm{H}_{2} \mathrm{O}$ (this lactose solution was prepared $24 \mathrm{~h}$ before use in order to reach the $\alpha$-lactose $\rightleftharpoons \beta$-lactose equilibrium).

$\mathrm{C}: 100 \mathrm{CO}\left(\mathrm{NH}_{2}\right)_{2}$.

The ultrafiltrate was obtained by mixing $330 \mathrm{ml} \mathrm{B}+10 \mathrm{ml} \mathrm{C}+615 \mathrm{ml}$ distilled water $+20 \mathrm{ml} \mathrm{A}_{1}+20 \mathrm{ml} \mathrm{A}_{2}+5.1 \mathrm{ml} 1 \mathrm{~N} \mathrm{KOH}(\mathrm{pH} \mathrm{6.6)}$.

In the diafiltration experiments for whey decalcification, $\mathrm{A}_{2}$ solution was $110 \mathrm{~g} \cdot \mathrm{I}^{-1}$ in $\mathrm{NaCl}$.

The «phosphate + calcium» solution contained :

1. $2.97 \mathrm{~g} .1^{-1}$

$\mathrm{K}_{2} \mathrm{HPO}_{4}, 3 \mathrm{H}_{2} \mathrm{O}$

2. $0.111 \mathrm{~g} .1^{-1}$

$\mathrm{CaCl}_{2}$

3. $2.85 \mathrm{ml} . \mathrm{l}^{-1}$

$3 \mathrm{~N} \mathrm{HCl}$

4. $2.95 \mathrm{~g} . \mathrm{l}^{-1}$

$\mathrm{NaCl}$

The solution was prepared in the order $1,3,4,2$ to prevent any calcium phosphate precipitation between 1 and 2. The ionic strength $(0.1)$ and $\mathrm{pH}$ (6.6) of the solution were similar to those of milk and whey. 


\section{Fluid analysis}

With the aim of characterizing each fluid, analyses were performed when the product was cold as well as when it entered the heat exchange fouling model. In the latter case the sample was cooled very rapidly to prevent subsequent heat dependent component changes.

Total solids were determined after oven drying at $103 \pm 2{ }^{\circ} \mathrm{C}$ for $7 \mathrm{~h}$ (Amariglio et al., 1973). Total nitrogen (TN) in deposits was found from $\mathrm{N} \times 6.38(\mathrm{OGG}, 1960)$ as measured by the micro-Kjeldahl technique. Contents of non casein nitrogen (NCN) and non protein nitrogen (NPN) were assessed by the method of Aschaffenburg and Drewry (1959). The difference between the two latter contents gave the content of total soluble proteins. The content of not denaturated $\beta$-lactoglobulin and $\alpha$-lactalbumin was determined by high pressure liquid chromatography (HPLC Varian 5000 ) in $0.01 \mathrm{M}$ tris-(hydroxymethyl) aminoethane buffer ( $\mathrm{pH}$ 6.68) on Varian Micropak TSK column +3000 SW silica gel.

Calcium was measured by atomic absorption spectrophotometry (Varian AA1275 Spectrometer). Phosphorus was determined after mineralization by spectrometry at a wavelength of $700 \mathrm{~nm}$ after warm reaction on sulphomolybdate reagent (Amariglio et al., 1973). Total calcium and total phosphorus were measured in the initial product, soluble calcium and phosphorus in an ultrafiltration permeate (ultrafiltration was performed on a conical Amicon CF 25 membrane at room temperature in a centrifuge $(1000 \times \mathrm{g}, 30 \mathrm{~min})$ (PIERRE et al., 1983)). Citrate content was determined by HPLC (Varian 5000 ) in $0.1 \%$ sulphuric acid buffer on a column (Aminex AS resin).

The $\mathrm{pH}$ value was measured by means of a $\mathrm{pH}$ meter (Radiometer Copenhagen $\mathrm{pH} \mathrm{M} 84$ ).

Table 1 shows analytical results of the different fouling fluids before and after forewarming at $72{ }^{\circ} \mathrm{C}$, i.e. at the inlet of the fouling-model.

\section{E. Fouling measurements}

\section{- Weighing}

Before and after the fouling test, samples were weighed (after $24 \mathrm{~h}$ of thermal and hygrometric equilibration at room temperature, dust protected) using a Mettler AE 163 balance. Undesirable edge effects obtained with milk were eliminated by scraping (in which case the scraped sample was weighed after careful cleaning) according to the previously described procedure. Deposit masses exceeding $3 \mu \mathrm{g} . \mathrm{cm}^{-2}$ were considered as significant (accuracy : $\left.\pm 2.5 \mu \mathrm{g} . \mathrm{cm}^{-2}\right)$. Each fouling test was repeated 3 times.

\section{procedures. \\ Auger electron and X Photoelectron (XPS) spectrometry and operating}

Auger and XPS analyses were made in the same apparatus under ultravacuum. Fouled plates were placed on a transfer bar in the introduction and 


\section{TABLE 1}

Chemical composition of fluids used for the fouling tests [figures between ( ) correspond to analysis carried out on the product at scale model inlet : $72^{\circ} \mathrm{Cl}$

Composition chimique des fluides utilisés pour les essais d'encrassement lles chiffres ( ) correspondent à l'analyse effectuée sur le produit à l'entrée de la maquette: $72{ }^{\circ} \mathrm{Cl}$

\begin{tabular}{|c|c|c|c|c|c|c|}
\hline & & Skim milk & Sweet whey & Whey + citrate & Artificial ultrafil. & $\begin{array}{l}\text { "Phosphate } \\
+ \text { calcium " }\end{array}$ \\
\hline TS & $\mathrm{g} \cdot \mathrm{kg}^{-1}$ & 90 & 63.2 & 66.3 & 58.9 & 3.6 \\
\hline NS & $\mathrm{g} \cdot \mathrm{kg}^{-1}$ & 33 & 9.7 & 9.7 & 0 & 0 \\
\hline NPN & $\mathrm{g} \cdot \mathrm{kg}^{-1}$ & 2.2 & 2.5 & 2.5 & 0 & 0 \\
\hline $\mathrm{NCN}$ & $\mathrm{g} \cdot \mathrm{kg}^{-1}$ & 7.4 & 7.4 & 7.4 & 0 & 0 \\
\hline$\alpha$-Lactalbumin & g. $1^{-1}$ & $1.03(0.78)$ & $0.8(0.77)$ & $0.8(0.71)$ & 0 & 0 \\
\hline$\beta$-Lactoglobulin & $\mathrm{g} . \mathrm{l}^{-1}$ & $3.38(3.00)$ & $3.10(2.90)$ & $3.10(2.78)$ & 0 & 0 \\
\hline Fat & $\mathrm{g} \cdot \mathrm{kg}^{-1}$ & 1.0 & 0.6 & 0.6 & 0 & 0 \\
\hline Lactose & g. $1^{-1}$ & 49.8 & 49 & 49 & 49.5 & 0 \\
\hline Citrate & $\mathrm{mg} \cdot \mathrm{I}^{-1}$ & $1990(2000)$ & $1760(1725)$ & $5325(5010)$ & $1601(1560)$ & 0 \\
\hline Total P & $\mathrm{mg} . \mathrm{l}^{-1}$ & $930(885)$ & $370(352)$ & $370(364)$ & 401 (369) & $400(380)$ \\
\hline Soluble P & $\mathrm{mg} \cdot 1^{-1}$ & $427(405)$ & $366(344)$ & $365(345)$ & $358(343)$ & $391(370)$ \\
\hline Total Ca & $\mathrm{mg} \cdot \mathrm{l}^{-1}$ & $1195(1170)$ & $351(351)$ & $351(359)$ & $400(383)$ & $40(38)$ \\
\hline Soluble Ca & $\mathrm{mg} \cdot \mathrm{l}^{-1}$ & 337 (287) & $332(319)$ & $335(330)$ & $362(303)$ & $36(9)$ \\
\hline $\mathrm{Na}$ & $\mathrm{mg} \cdot 1^{-1}$ & - & 400 & 992 & 364 & 69 \\
\hline K & $\mathrm{mg} \cdot 1^{-1}$ & - & 1300 & 1476 & 1601 & 984 \\
\hline $\mathrm{Cl}$ & $\mathrm{mg} \cdot \mathrm{1}^{-1}$ & - & 1130 & 1130 & 1180 & 480 \\
\hline $\mathrm{pH}$ & - & 6.5 & 6.5 & 6.6 & 6.6 & 6.6 \\
\hline
\end{tabular}


preparation chamber. If required the sample was ionically eroded with an Argon ion gun (4-6 KV). The pressure was $10^{-7}$ torr. By means of magnetic transfer, the sample was placed in the middle of a second chamber (measurement chamber), and positionned for Auger or XPS at a pressure of $5 \times 10^{-9}$ to $5 \times 10^{-10}$ torr.

Auger electron spectrometry was performed with a CMA Riber analyser fitted with a coaxial electron gun providing a high luminosity. The spectra

were generally obtained by means of synchronous detection. $E \frac{d N(E)}{d E}$ was obtained.

XPS measurements were carried out with an HA 100 VSW hemispherical analyser. A twin $\mathrm{Mg} / \mathrm{Al} \mathrm{X}$-ray source (K$\alpha$ radiation) was used. Results were generally obtained with $50 \mathrm{eV}$ transition energy for the general spectra and $25 \mathrm{eV}$ for the profiles, the source energy being 130 and $260 \mathrm{~W}$, respectively. The angle between the source and the lens axis of the analyser was about $55^{\circ}$ and the electron emission angle of the substrate was variable (generally $15^{\circ}$ relative to the normal). Changing this angle allowed the electrons studied to be issued from different areas inside the sample.

When interpreting sprectra, the layers analyzed were assumed to be homogeneous and possible variations due to different attenuation lengths were not corrected.

\section{F. Infrared spectrometry}

Various tests performed with specular or total attenuated reflection techniques being unsatisfactory, the spectra were plotted by transmission after micropelleting. Two milligrams of powder $(\mathrm{KBr}, \mathrm{CsBr})$ finely ground in a sapphire micromortar were spread on the metal surface. The various substances to be studied were trapped by adsorption after a very fine erosion obtained with a microspatula. A second operation improved the recovery by eliminating the alkaline halogenide from the polishing striae.

Spectra were obtained with two different spectrometers, i.e. a dispersive 457 Perkin-Elmer routine spectrometer with a beam condenser and a Brucker (Fourier transformed) spectrometer (type 45). The spectra were of good quality, characterized by bands well defined as for their exact position or multiplicity. Three main groups of substances with characteristic functions could be distinguished :

- proteins, p, characterized by their peptide - CO-NH- bonds were measured by their stronger amide band $\left(v_{\mathrm{c}=0}\right.$ at $\left.1650 \mathrm{~cm}^{-1}\right)$ rathan than by the $\mathrm{N}-\mathrm{H}$ bonds (3 300 and $1540 \mathrm{~cm}^{-1}$ );

- lipids, 1, for which only the ester function $\left(v_{\mathrm{c}=0}\right.$ at $\left.1745 \mathrm{~cm}^{-1}\right)$ was characteristic ;

- phosphates, $\mathrm{PO}_{4}{ }^{3-}$, were detected between 1000 and $1100 \mathrm{~cm}^{-1}$ by a strong triply degenerate band $\left(v_{3}\right)$ in a range where proteins did not absorb. A second band around $600 \mathrm{~cm}^{-1}$ (also triply degenerate but weaker) is even more sensitive than the former to the degree of phosphate organization (crystallinity, type of lattice), but less useful for the calculations. 
It was thus possible to ensure a semi-quantitative measurement of the three substances (expressed in percent) :

$$
1+p+\mathrm{PO}_{4}=100
$$

Measuring inner absorbance ratios $\mathrm{A}_{\mathrm{i}} / \mathrm{A}_{\mathrm{j}}\left(\mathrm{i}, \mathrm{j}=1\right.$ or $\mathrm{p}$ or $\mathrm{PO}_{4}$ ) and applying Beer's law with conditional extinction coefficients, valid for definite operating conditions :

$$
\begin{aligned}
& \frac{1}{\mathrm{p}}=\frac{\varepsilon_{\mathrm{p}}}{\epsilon_{\mathrm{l}}} \cdot \frac{\mathrm{A}_{1}}{\mathrm{~A}_{\mathrm{p}}} \\
& \frac{\mathrm{PO}_{4}}{\mathrm{p}}=\frac{\varepsilon_{\mathrm{p}}}{\varepsilon_{\mathrm{p} 0_{4}}} \cdot \frac{\mathrm{A}_{\mathrm{PO}^{4}}}{\mathrm{~A}_{\mathrm{p}}}
\end{aligned}
$$

The $\varepsilon_{\mathrm{i}} / \varepsilon_{\mathrm{j}}$ were known from a series of standard mixtures. A programme was developed to substract, at each frequency $\left(1650 \mathrm{~cm}^{-1}\right.$ for $\mathrm{p}, 1745 \mathrm{~cm}^{-1}$ for $1,1040 \mathrm{~cm}^{-1}$ for $\mathrm{PO}_{4}$ ), the (small) contribution of both other compounds to the total absorbance and display the results with the adequate units (mass $\%$, mole $\% \ldots$...).

Experiments confirmed the possibility of estimating small amounts of lipids. In such a case, the C-O band (strongest), even shifted to a lower wave number, can always be localized on the amide band side at the $1 \%$ level without any deconvolution on the FTIR Spectra. Of course, the accuracy is very poor at such a level. Difficulties linked to $\mathrm{PO}_{4}$ measurements can arise from spectral interference (C-C vibrations for instance). As a matter of fact, the main problem is the presence of aromatic rings in various proportions, as the programme correction (computed for $\beta$-lactoglobulin) is no longer valid. Such a problem was easily solved by grinding the $\mathrm{CsBr}$ pellet and heating at $600{ }^{\circ} \mathrm{C}$ in a platinum microdish $(5 \mathrm{~mm}$ diameter $)$. A new spectrum with enhanced sensitivity only evidenced $\mathrm{Ca}_{3}\left(\mathrm{PO}_{4}\right)_{2}$, readily detected on FTIR plots (characteristic profile and almost identical absorbance).

\section{Results}

\section{A. Fouling as a function of whey treatment temperature}

In this series, fouling tests were performed with a temperature difference of $\Delta \mathrm{T}=10^{\circ} \mathrm{C}$ and lasted $10 \mathrm{~min}$. Deposit masses varied only slightly (always below $10 \mu \mathrm{g} . \mathrm{cm}^{-2}$ ) between 25 and $56^{\circ} \mathrm{C}$, then strongly increased, especially from $60-70{ }^{\circ} \mathrm{C}$ (fig. 1 ).

Auger spectra recorded on surfaces fouled at $64{ }^{\circ} \mathrm{C}$ did not reveal any calcium $(\mathrm{Ca})$, only traces of phosphorus (P), but large quantities of carbon (C), oxygen (O) and nitrogen (N). At 72 and $88^{\circ} \mathrm{C}, \mathrm{Ca}$ and $\mathrm{P}$ appeared in large amounts as well as $\mathrm{O}, \mathrm{C}, \mathrm{N}$, but the amount of the latter two elements did not increase proportionally to the deposit mass (table 2). Results obtained with infrared spectrometry showed that the small-scale model idea is fully justified as at the same temperature, results were totally different when using such a device or by dipping a clean plate directly into a heated beaker. In the 
latter case, at $48{ }^{\circ} \mathrm{C}$, the ratio between absorbances at $1745 \mathrm{~cm}^{-1}$ (lipids) and $1650 \mathrm{~cm}^{-1}$ (proteins) was multiplied by 20 , indicating the tremendous importance of lipids collected at the air-solution interface. This clearly showed the absolute necessity of working in dynamic conditions.
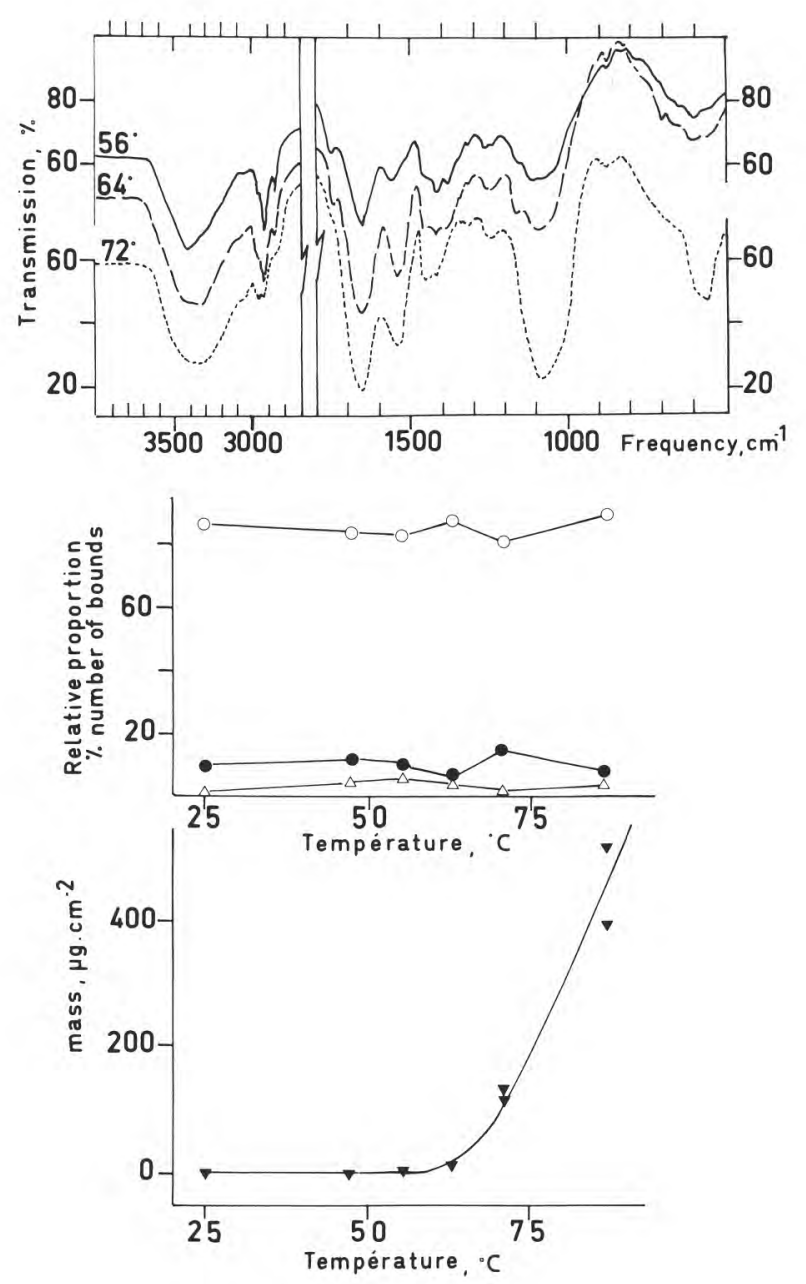

Fig. 1

Fouling with lactoserum $v s$. temperature $\left(v=0.096 \mathrm{~m} \cdot \mathrm{s}^{-1}\right.$, time in preheater: $28 \mathrm{~s}$; $\Delta T=10^{\circ} \mathrm{C}$; duration: $\left.10 \mathrm{~min}\right)$ : masses and relative proportions of proteins $(\mathrm{O})$, phosphates $(\bullet)$ and lipids $(\triangle)$ computed from IR Spectra.

Encrassement par le lactosérum en fonction de la température $\left(v=0,096 \mathrm{~m} \cdot \mathrm{s}^{-1} ;\right.$ durée de préchauffage: $28 \mathrm{~s} ; \Delta T=10^{\circ} \mathrm{C}$; durée : $\left.10 \mathrm{mn}\right)$ : masses et proportions relatives de protéines $(\bigcirc)$, phosphates $(\bullet)$ et lipides $(\triangle)$ calculées à partir des spectres infrarouges. 
Changes in IR spectra vs. temperature revealed the following facts :

- the most important fraction of the deposit consisted of proteins (1 650, $1540 \mathrm{~cm}^{-1}$ ) which trend was reinforced by the beginning of their denaturation $\left(64^{\circ} \mathrm{C}\right)$;

- the relative amount of phosphates (1 000-1 $100 \mathrm{~cm}^{-1}$ and around 600 $\mathrm{cm}^{-1}$ ) can never be totally neglected, even if their quantity was very low at low temperature (under $64{ }^{\circ} \mathrm{C}$ a $5 \mathrm{x}$ scale expansion was required to measure the spectra). Their content markedly increased between $64{ }^{\circ} \mathrm{C}(7 \%)$ and $72{ }^{\circ} \mathrm{C}$ $(17 \%)$, but they never exceeded those of proteins (fig. 1) while the masses varied in an even more spectacular way (x10);

- lipids $\left(1745,2850 \mathrm{~cm}^{-1}\right)$ were very small around $72{ }^{\circ} \mathrm{C}$.

The most striking modification of the organic deposit fraction concerned the large variation of the carboxylate functions $\left(1400 \mathrm{~cm}^{-1}\right)$ as compared to $-\mathrm{CH}_{2}$ - chains $\left(1450 \mathrm{~cm}^{-1}\right)$ : the ratio between the corresponding absorbances decreased from 1.3 to 0.3 between 56 and $72{ }^{\circ} \mathrm{C}$ where the value was minimum.

\section{B. Kinetics of fouling by the different model fluids}

The masses of deposit with the "phosphate + calcium " solution were significant from the very first minute (fig. 2). The increase of these masses with time was linear :

$$
\begin{aligned}
& \mathrm{m}=18.2 \mathrm{t}-4.7 ; \mathrm{r}=0.992 \text { for } \Delta \mathrm{T}=5{ }^{\circ} \mathrm{C} ; \\
& \mathrm{m}=17.3 \mathrm{t}-8.9 ; \mathrm{r}=0.997 \text { for } \Delta \mathrm{T}=0{ }^{\circ} \mathrm{C} \text {. }
\end{aligned}
$$

Thus, apart from the first instants where the rate was slower, 0 order kinetics was observed.

As no simple kinetic law ( 0 to 2 order) could be developed with the other fluids, all results appear in figure 2 as « deposit masses vs. time».

The synthetic ultrafiltrate was more heat stable than the former solution, i.e. only $16 \%$ calcium were insolubilized by the preheating treatment (table 1). Deposit masses were much lower (fig. 2, curve 2). After a first phase lasting about $5 \mathrm{~min}$ during which the masses increased only slightly $\left(<10 \mu \mathrm{g} . \mathrm{cm}^{-2}\right)$, the fouling increased, more markedly for $\Delta \mathrm{T}=5^{\circ} \mathrm{C}$ than for $\Delta \mathrm{T}=0{ }^{\circ} \mathrm{C}$.

The heat stability of sweet whey is even higher since only $4 \%$ of soluble calcium were insolubilized during tests at $72{ }^{\circ} \mathrm{C}$. As for the ultrafiltrate, deposit masses increased more rapidly for $\Delta \mathrm{T}=5{ }^{\circ} \mathrm{C}$ than for $\Delta \mathrm{T}=0{ }^{\circ} \mathrm{C}$ (fig. 2). Until $5 \mathrm{~min}$, whey seemed to be more foulant than the ultrafiltrate. Beyond that length of time, deposit grew at similar rates for both fluids, but the fouling capacity of whey regressed. At $88^{\circ} \mathrm{C}$, the results were qualitatively similar, i.e. low fouling rates up to $1 \mathrm{~min}$ followed by a marked increase to $160 \mu \mathrm{g} . \mathrm{cm}^{-2}$ after about $5 \mathrm{~min}$ and $2200 \mu \mathrm{g} . \mathrm{cm}^{-2}$ after $20 \mathrm{~min}$ (fig. 3). Between 20 and $40 \mathrm{~min}$, the filling-in of the flow channel was so marked that the circulation velocity of the fluid (increasing with decreasing hydraulic diameter), hindered fouling and therefore reduced the deposit formation rate. 


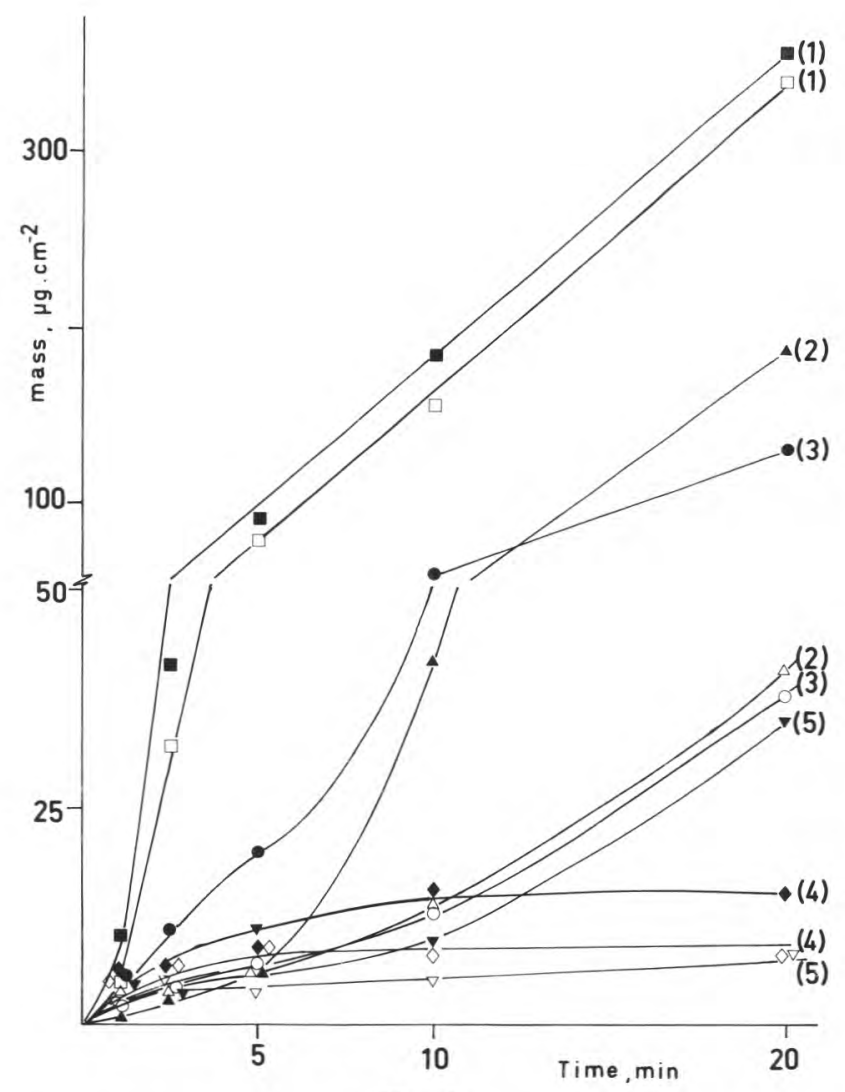

Fig. 2

Kinetics of $304 \mathrm{~L}$ Stainless steel fouling by model fluids $\left(v=0.096 \mathrm{~m} . \mathrm{s}^{-1}\right.$; time in preheater: $28 \mathrm{~s} ; \mathrm{T}=72{ }^{\circ} \mathrm{C}$ ).

Cinétique d'encrassement d'un acier inoxydable $304 \mathrm{~L}$ par des fluides modèles $\left(v=0,096 \mathrm{~m} \cdot \mathrm{s}^{-1}\right.$; durée de préchauffage : $\left.28 \mathrm{~s} ; \mathrm{T}=72{ }^{\circ} \mathrm{C}\right)$.

" phosphate + calcium»

Artificial permeate/Ultrafiltrat synthétique Sweet whey/Lactosérum doux

Decalcified whey/Lactosérum décalcifié

Skim milk/Lait écrémé
$\Delta T$

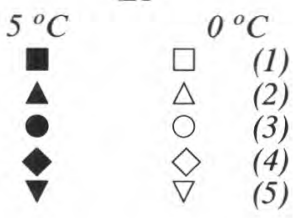

In the case of whey "with no calcium precipitable ", soluble calcium was fully stabilized by citrate and no calcium precipitation was observed during preheating (table 1). Deposit masses remained reduced even after long lengths of time $\left(14 \mu \mathrm{g} \cdot \mathrm{cm}^{-2}\right.$ after $20 \mathrm{~min}$ at $\Delta \mathrm{T}=5^{\circ} \mathrm{C}$ ) (fig. 2). A plateau (higher for $\Delta \mathrm{T}=5{ }^{\circ} \mathrm{C}$ than for $\Delta \mathrm{T}=0{ }^{\circ} \mathrm{C}$ ) was reached after about $10 \mathrm{~min}$. Fouling kinetics with whey and complexed calcium whey were of the same order up to $5 \mathrm{~min}$. 

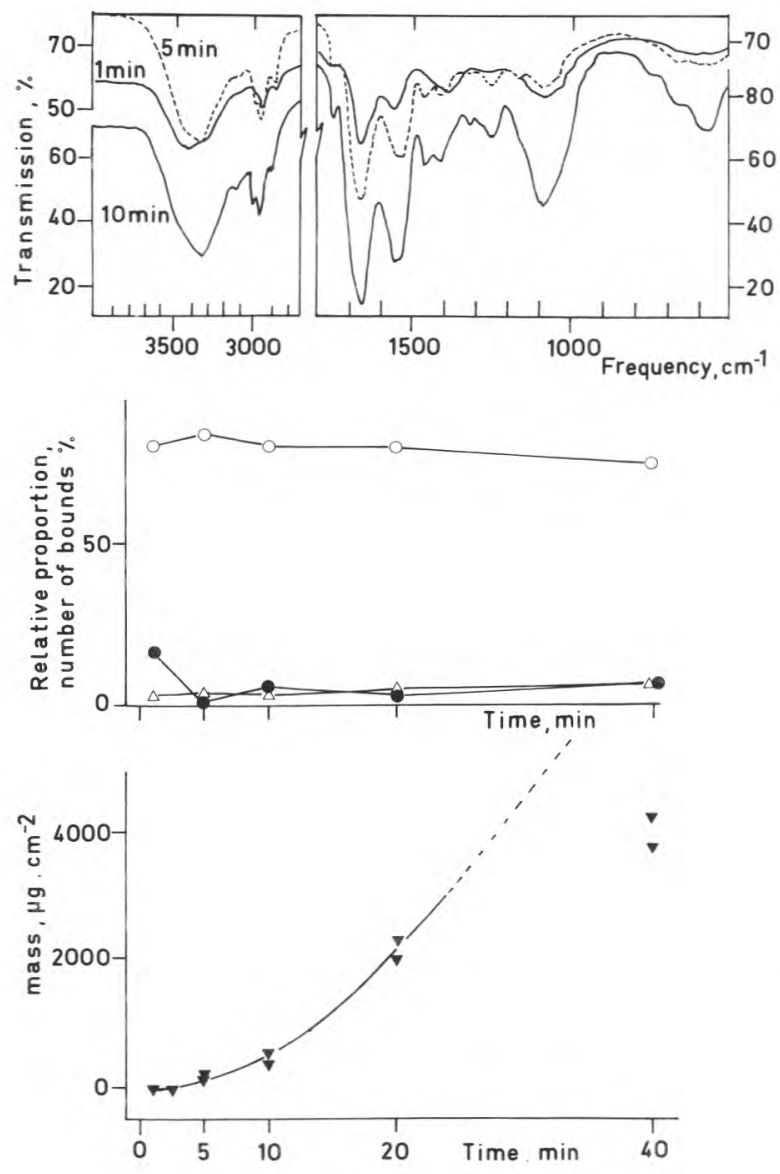

Fig. 3

Fouling with lactoserum vs. time at $88^{\circ} \mathrm{C}\left(v=0.096 \mathrm{~m} . \mathrm{s}^{-1}\right.$; time in preheater : $28 \mathrm{~s}$. ; $\Delta T=10^{\circ} \mathrm{C}$ ) : masses and variation of relative proprotions of proteins (O) phosphates and lipids $(\triangle)$ computed from IR spectra, versus time.

Encrassement par le lactosérum en fonction du temps à $88^{\circ} \mathrm{C}\left(v=0,096 \mathrm{~m} \cdot \mathrm{s}^{-1}\right.$; durée de préchauffage : $28 \mathrm{~s} ; \Delta T=10^{\circ} \mathrm{C}$ ) : masses et variation des proportions relatives des protéines $(\bigcirc)$, phosphates $(-)$ et lipides $(\triangle)$ calculées à partir des spectres infrarouges.

Fouling caused by skimmilk increased much less for $\Delta \mathrm{T}=0{ }^{\circ} \mathrm{C}\left(8 \mu \mathrm{g} \cdot \mathrm{cm}^{-2}\right.$ after $20 \mathrm{~min}$ ) than for $\Delta \mathrm{T}=5{ }^{\circ} \mathrm{C}$ where the kinetics remained much slower than in the case of whey (fig. 2). Preheating of milk resulted in a shift of $15 \%$ soluble calcium towards the colloidal phase or a precipitated inorganic form and a denaturation of about $20 \%$ of both soluble proteins, $\beta$-lactoglobulin and $\alpha$-lactalbumin (table 1). 


\section{Spectroscopic characteristics}

\section{"phosphate + calcium " solution}

Auger analysis evidenced neither potassium (K), nor chlorine $(\mathrm{Cl})$ or sodium $(\mathrm{Na})$, but detected calcium $(\mathrm{Ca})$, phosphorus $(\mathrm{P})$ and oxygen $(\mathrm{O})$ in the form of phosphate and $\mathrm{Ca}-\mathrm{O}$ (table 2). The IR spectra were characterized by two ranges of strong absorption about $1000-1100 \mathrm{~cm}^{-1}$ and around $600 \mathrm{~cm}^{-1}$ (fig. 4). The bands were multiple with very sharp peaks showing the crystalline character of the substance. Both absorption ranges were easy to identify with the modes of antisymmetrical stretching vibration ( $\nu_{3}$, $\left.1000-1110 \mathrm{~cm}^{-1}\right)$ and antisymmetrical bending vibration $\left(v_{4}, 600 \mathrm{~cm}^{-1}\right)$ of the $\mathrm{PO}_{4}$ ion. A strong spectrum evidenced water : bands (unseparated) at 3250 , $3400,3500 \mathrm{~cm}^{-1}$ for the stretching $\nu_{0-\mathrm{H}}$ mode and $1640 \mathrm{~cm}^{-1}$ for $\delta_{\mathrm{H}-0-\mathrm{H}}$ bending.

Many small additional bands confirmed the fact that this substance was not a classical one (e.g. apatite, brushite, monetite). X-rays confirmed the presence of a mixture of calcium hydrogenphosphates, $\mathrm{Ca}_{4} \mathrm{H}\left(\mathrm{PO}_{4}\right)_{3}, 2 \mathrm{H}_{2} \mathrm{O}$ and $\mathrm{Ca}_{4} \mathrm{H}\left(\mathrm{PO}_{4}\right)_{3}, 3 \mathrm{H}_{2} \mathrm{O}$ (ASTM No 11-184 and 391, respectively).

\section{Synthetic ultrafiltrate}

Auger analysis revealed traces of sulphur (S), silicon (Si), chlorine $(\mathrm{Cl})$, phosphorus (P) and calcium (Ca) in the smallest deposits $\left(<5 \mu \mathrm{g} \cdot \mathrm{cm}^{-2}\right)$. There were large amounts of oxygen $(\mathrm{O})$, but neither carbon $(\mathrm{C})$ nor nitrogen (N) (table 2). Larger deposits particularly for $\Delta \mathrm{T}=5{ }^{\circ} \mathrm{C}$, contained $\mathrm{P}, \mathrm{O}$ and $\mathrm{Ca}$ and traces of $\mathrm{K}$ and $\mathrm{N}$. The XPS analysis of the deposit formed after a running time of $10 \mathrm{~min}$ indicated that $\mathrm{P}(13 \%)$ and $\mathrm{Ca}(17 \%)$ were involved in $\mathrm{P}-\mathrm{O}$ and $\mathrm{Ca}-\mathrm{O}$ bonds, respectively. The very high proportion of oxygen $(\approx 70 \%)$ revealed the subjacent presence of chromium and iron oxides.

After long enough running times ( $>5 \mathrm{~min}$ ) the IR spectrum had always the same appearance (fig. 4), i.e. two phosphate bands with two main peaks each $\left(1040 \mathrm{~cm}^{-1}\right.$ and $1100 \mathrm{~cm}^{-1} ; 570 \mathrm{~cm}^{-1}$ and $\left.605 \mathrm{~cm}^{-1}\right)$ as for apatites. In addition to water, visible at $3400 \mathrm{~cm}^{-1}$ and $1630 \mathrm{~cm}^{-1}$, organic matter also was observed $\left(v_{\mathrm{C}-H}\right.$ around $\left.2900 \mathrm{~cm}^{-1}\right)$ as well as two rather complex bands towards $1600 \mathrm{~cm}^{-1}$ and $1400-1500 \mathrm{~cm}^{-1}$ (triple) and a small absorption at 875 $\mathrm{cm}^{-1}$. The $\nu_{\mathrm{O}-\mathrm{H}}$ mode of hydroxyapatite did not appear.

The presence of organic substances was always detected after short running times $(2.5 \mathrm{~min})$. The appearance of the spectrum between 1000 and $1800 \mathrm{~cm}^{-1}$ was compatible with the presence of a complex based on citrate ions, but lactose could not be detected; there was a large contribution of carbon-hydrogen bands $\left(v_{\mathrm{s}} \mathrm{CH}_{2}: 2850 \mathrm{~cm}^{-1}, v_{\text {as }} \mathrm{CH}_{2}: 2925 \mathrm{~cm}^{-1}\right)$, involving other compounds which could not be separated from the pollution. The $\mathrm{A}_{2925} /$ $\mathrm{A}_{1040}$ ratio reached a value of $7\left(\Delta \mathrm{T}=0{ }^{\circ} \mathrm{C} ; 2.5 \mathrm{~min}\right)$ or $2.5\left(\Delta \mathrm{T}=5{ }^{\circ} \mathrm{C} ; 3 \mathrm{~min}\right)$ accounting for the importance of $\mathrm{C}-\mathrm{H}$ bonds relative to $\mathrm{P}-\mathrm{O}\left(\mathrm{PO}_{4}\right)$ bonds. Profiles of the relative variations of proteins, phosphates and lipids are given in figure 5. The synthetic ultrafiltrate fluid for which this measurement had 


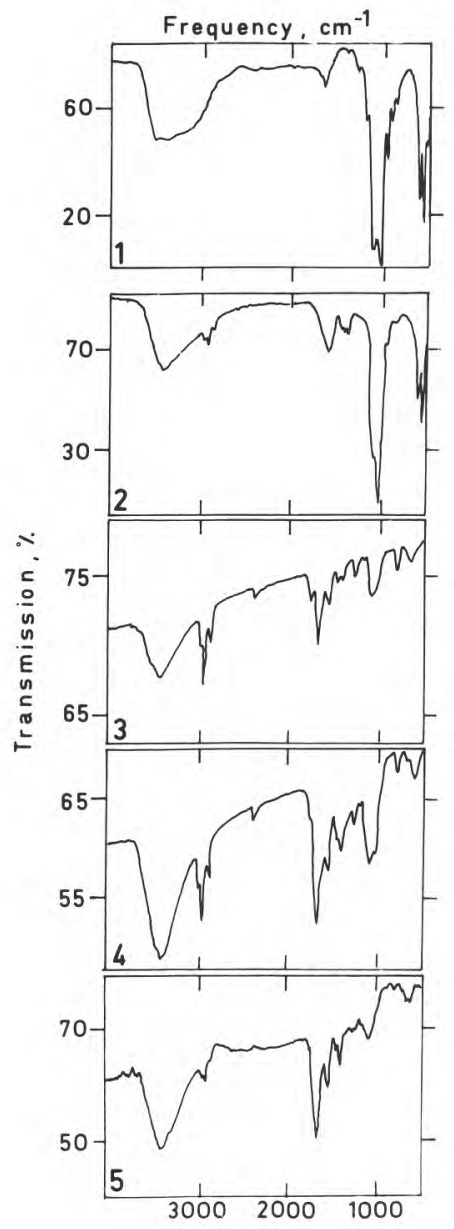

Fig. 4

IR spectra of deposits removed from the surface after fouling with various model solutions at $72{ }^{\circ} \mathrm{C}$.

Spectres infrarouges des dépôts récupérés sur la surface après encrassement par différentes solutions modèles à $72{ }^{\circ} \mathrm{C}$.

1. "phosphate + calcium "

2. Artificial permeate/ultrafiltrat synthétique

3. Sweet whey/lactosérum doux

4. Decalcified whey/lactosérum décalcifié

5. Skim milk/lait écrémé
$-10 \mathrm{~min} ; \Delta T=5^{\circ} \mathrm{C}$

$-10 \mathrm{~min} ; \Delta T=5^{\circ} \mathrm{C}$

- $5 \mathrm{~min} ; \Delta T=0^{\circ} \mathrm{C}$

- $5 \min ; \Delta T=5^{\circ} \mathrm{C}$

$-20 \mathrm{~min} ; \Delta T=5^{\circ} \mathrm{C}$

strictly no signification was also computed with the aim of showing two facts : the predominance of calcium phosphate was progressive and could not be observed before $5 \mathrm{~min}$; it occurred earlier in the presence of a temperature gradient (higher wall temperature together with a gradient between the latter and the temperature inside the fluid). 
TABLE 2

Results from Auger electron and $X$ photoelectron spectroscopy for fouling deposits built up with the various fluids Résultats obtenus par spectroscopie d'électrons Auger et de photoélectrons X sur les dépôts d'encrassement relatifs aux différents fluides

\begin{tabular}{|c|c|c|c|c|c|c|c|c|c|}
\hline \multirow{3}{*}{ Fluid } & & \multirow{3}{*}{$\Delta \mathrm{T}$} & \multirow{3}{*}{$\begin{array}{c}\text { Time } \\
t(\min )\end{array}$} & $\mathrm{C}$ & $\mathrm{O}$ & $\mathrm{N}$ & $\mathrm{Ca}$ & $\mathrm{P}$ & \multirow{3}{*}{ Remarks } \\
\hline & & & & \multicolumn{5}{|c|}{ Type } & \\
\hline & & & & $\begin{array}{l}-\mathrm{CH} \\
-\mathrm{CO}_{2}^{-} \\
\end{array}$ & $\begin{array}{c}- \text { OH } \\
- \text { Ox. Metal } \\
\end{array}$ & $\begin{array}{c}\mathrm{NH}_{2} \\
-\mathrm{N}=\mathrm{CH}\end{array}$ & $\mathrm{CaO}$ & $\mathrm{PO}_{4}^{3-}$ & \\
\hline \multirow{2}{*}{$\begin{array}{c}\text { «phosphate } \\
+ \\
\text { calcium » }\end{array}$} & \multirow{2}{*}{72} & 5 & $\begin{array}{l}1 \\
2.5 \\
5\end{array}$ & $\begin{array}{l}+(a) \\
+ \\
+\end{array}$ & $\begin{array}{l}+ \\
+ \\
+\end{array}$ & $\begin{array}{l}- \\
- \\
-\end{array}$ & $\begin{array}{l}+ \\
+ \\
+\end{array}$ & $\begin{array}{l}+ \\
+ \\
+\end{array}$ & \multirow[t]{2}{*}{$\begin{array}{l}\text { - traces of } \mathrm{K}, \mathrm{Cl} \\
\text { - No N }\end{array}$} \\
\hline & & 0 & 5 & + & + & - & + & + & \\
\hline \multirow{2}{*}{$\begin{array}{l}\text { artificial } \\
\text { permeate }\end{array}$} & \multirow{2}{*}{72} & 5 & $\begin{array}{l}2.5 \\
5 \\
10\end{array}$ & $\begin{array}{l}+ \\
+ \\
+ \\
\end{array}$ & $\begin{array}{l}+ \\
+ \\
+\end{array}$ & $\begin{array}{l}- \\
- \\
-\end{array}$ & $\begin{array}{l}+ \\
+ \\
+\end{array}$ & $\begin{array}{l}+ \\
+ \\
+\end{array}$ & \multirow{2}{*}{$\begin{array}{l}\text { - traces of } \mathrm{N} \text { after } 20 \mathrm{~min} \\
\text { - C very weak after } \\
\text { a light sputtering } \\
\text { - traces of } \mathrm{S}, \mathrm{Si}, \mathrm{Cl}\end{array}$} \\
\hline & & 0 & $\begin{array}{l}1 \\
2.5 \\
5\end{array}$ & $\begin{array}{l}+(a) \\
+ \\
+\end{array}$ & $\begin{array}{l}+(a) \\
+ \\
+\end{array}$ & $\begin{array}{l}- \\
- \\
-\end{array}$ & $\begin{array}{l}- \\
- \\
+\end{array}$ & $\begin{array}{l}- \\
- \\
+\end{array}$ & \\
\hline \multirow{3}{*}{ whey } & 64 & 10 & 10 & + & + & + & - & - & \multirow[t]{3}{*}{ - traces of P within the deposit } \\
\hline & 72 & $\begin{array}{r}5 \\
5 \\
5 \\
10 \\
5\end{array}$ & $\begin{array}{l}2.5 \\
5 \\
10 \\
10 \\
20\end{array}$ & $\begin{array}{l}+ \\
+ \\
+ \\
+ \\
+\end{array}$ & $\begin{array}{l}+(b) \\
+ \\
+ \\
+ \\
+\end{array}$ & $\begin{array}{l}+ \\
+ \\
+ \\
+ \\
+\end{array}$ & $\begin{array}{l}- \\
+ \\
+ \\
+ \\
+\end{array}$ & $\begin{array}{l}- \\
+ \\
+ \\
+ \\
+\end{array}$ & \\
\hline & 88 & 10 & $\begin{array}{r}1 \\
5 \\
10\end{array}$ & $\begin{array}{l}+ \\
+ \\
+\end{array}$ & $\begin{array}{l}+ \\
+ \\
+\end{array}$ & $\begin{array}{l}+ \\
+ \\
+\end{array}$ & $\begin{array}{l}- \\
+ \\
+\end{array}$ & $\begin{array}{l}- \\
+ \\
+\end{array}$ & \\
\hline \multirow{2}{*}{$\begin{array}{l}\text { Decalcified whey } \\
\text { sequestrated Ca } \\
\text { Diafiltered }\end{array}$} & \multirow{2}{*}{72} & $\begin{array}{l}0 \\
5\end{array}$ & $\begin{array}{l}2.5 \\
10\end{array}$ & $\begin{array}{l}+ \\
+\end{array}$ & $\begin{array}{l}+(b) \\
+(b)\end{array}$ & $\begin{array}{l}+ \\
+\end{array}$ & - & - & \\
\hline & & 5 & 10 & + & $+(b)$ & + & - & - & \\
\hline skim milk & 72 & 5 & 10 & + & $+(b)$ & + & - & - & \\
\hline \multicolumn{10}{|c|}{$\begin{array}{l}\text { (a) } \mathrm{C} \text { and } \mathrm{O} \text { always as atmospheric contamination } \\
\mathrm{C} \text { decreases sharply after light sputtering and gives a carbide } \\
\text { (b) } \mathrm{O} \text { must be partly assigned to oxides of metallic substrate. }\end{array}$} \\
\hline
\end{tabular}




\section{E. Whey}

The Auger analysis of the control sample which had been into contact with distilled water showed neither calcium nor phosphorus, but an atmospheric pollution $(\mathrm{C}, \mathrm{O}, \mathrm{N})$ which rapidly disappeared as affected by the ionic erosion, revealing the passive layer of stainless steel.

Fouling tests with whey at $88^{\circ} \mathrm{C}, \Delta \mathrm{T}=10^{\circ} \mathrm{C}$, did not reveal either $\mathrm{Ca}$ or $\mathrm{P}$ after a running time of $1 \mathrm{~min}$. But nitrogen was present (in a lower amount than $\mathrm{C}$ and $\mathrm{O}$ ) and contrary to the former case, it did not disappear rapidly during erosion. Accordingly, it was not an atmospheric pollution but nitrogenous whey components. $\mathrm{Ca}$ and $\mathrm{P}$ appeared at $\mathrm{t}=5 \mathrm{~min}$ (table 2 ). The calcium concentration in the deeper deposit layer, estimated by analysis after successive ionic erosions, passed by a maximum before disappearing in a rather deep position. At $\mathrm{t}=10 \mathrm{~min}$, the deposit was much thicker $\left(397 \mu \mathrm{g} \cdot \mathrm{cm}^{-2}\right)$ and the prolonged bombardment ( 8 erosions during $38 \mathrm{~min}$ ) led to a blackening. Changes in the amounts of nitrogen, calcium and phosphorus were almost parallel. However, there was a very marked rise in $\mathrm{Ca}$ and $\mathrm{N}$ concentrations, due to the increasing deposit mass (fig. 3), but with a $\mathrm{Ca} / \mathrm{N}$ ratio increasing from 0.6 to about 3 between 5 and $10 \mathrm{~min}$ fouling; this corresponds to the increase in the amount of phosphates observed in IR.

At $72{ }^{\circ} \mathrm{C}$, XPS analysis only revealed the presence of small quantities of $\mathrm{Ca}$ and $\mathrm{P}$ after $5 \mathrm{~min}$ of fouling with $\Delta \mathrm{T}=5^{\circ} \mathrm{C}$ whereas $\mathrm{C}, \mathrm{O}$ and $\mathrm{N}$ were already detected after $2.5 \mathrm{~min}$, together with $\mathrm{Fe}\left(\mathrm{Fe}_{2} \mathrm{O}_{3}\right), \mathrm{Cr}\left(\mathrm{Cr}_{2} \mathrm{O}_{3}\right)$ and silicon (silicate). There was thus a fundamental difference with results obtained by Auger for the sample of the previous series at $72^{\circ} \mathrm{C}\left(\Delta \mathrm{T}=10^{\circ} \mathrm{C}, 10 \mathrm{~min}\right)$ in which a large amount of calcium phosphate was detected. This corresponded to the very low phosphate contents detected by IR (fig. 5) between 2.5 and $10 \mathrm{~min}$. However, the latter technique allowed phosphates to be evidenced at $\mathrm{t}=1$ min after elimination of the organic matter by heat treatment $\left(600^{\circ} \mathrm{C}\right)$ and for both conditions : $\Delta \mathrm{T}=0{ }^{\circ} \mathrm{C}, \Delta \mathrm{T}=5{ }^{\circ} \mathrm{C}$. The profile of $\mathrm{PO}_{4}^{3}$ bands was interesting, i.e. before calcination none of the two bands was resolved : the structure was less organized than in the case of the ultrafiltrate. The $\nu_{3}\left(\mathrm{PO}_{4}\right)$ band was maximum at $1080 \mathrm{~cm}^{-1}$ with a shoulder at $1040 \mathrm{~cm}^{-1}$. Heating at $600{ }^{\circ} \mathrm{C}$ led to a maximum of $1040 \mathrm{~cm}^{-1}$ with a second peak at $1100 \mathrm{~cm}^{-1}$ characterizing a recrystallization as tricalcium phosphate. The presence of phosphates was thus confirmed for very short running times (1 $\mathrm{min})$. Their absorbance, unchanged for $\Delta \mathrm{T}=0{ }^{\circ} \mathrm{C}$, decreased however for $\Delta \mathrm{T}=5^{\circ} \mathrm{C}$; for these low levels there may be interference with substances (for instance lactose) which were soluble in our experimental conditions and which should have been eliminated by rinsing after the fouling test.

In terms of relative proportions, two main facts should be pointed out : the phosphate content exhibits a minimum value, observed later for $\Delta \mathrm{T}=5^{\circ} \mathrm{C}$ (fig. 5) than for $\Delta \mathrm{T}=10^{\circ} \mathrm{C}$ (fig. 3); the presence of larger amounts of proteins, even during the phase of rapid growth for calcium phosphate (fig. 5, $20 \mathrm{~min}$ ) confirms the existence of a protein-calcium-phosphate interaction. 


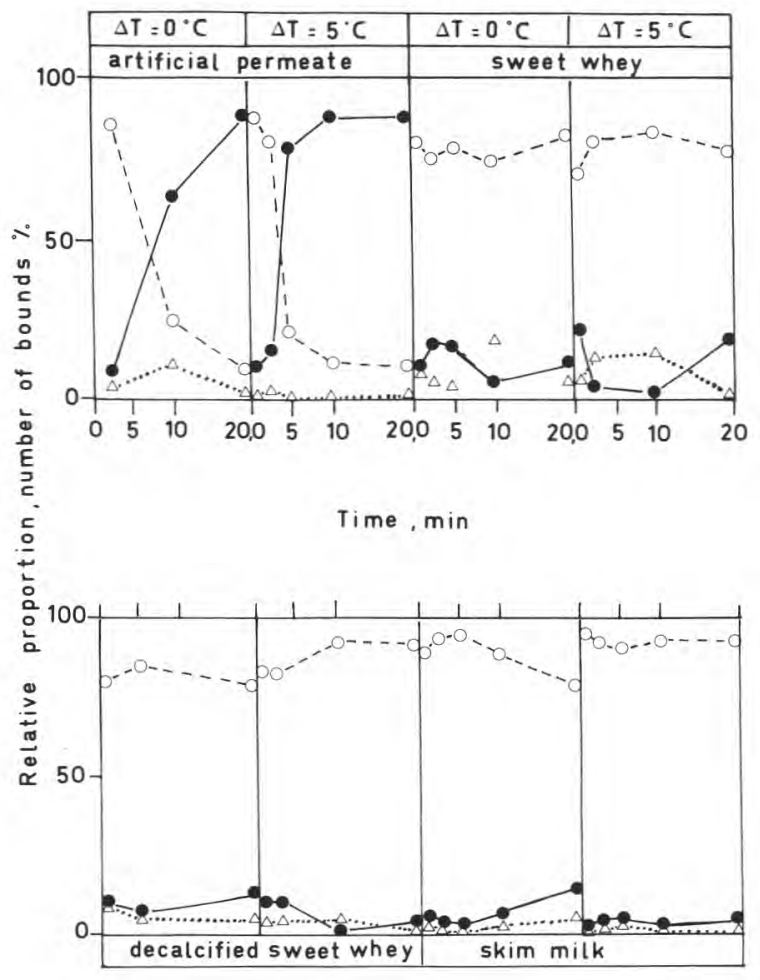

Fig. 5

Modelized composition of deposits obtained from model fluids vs. time lproteins (○),

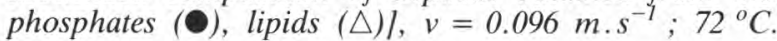

Evolution au cours du temps de la composition modélisée des dépôts obtenus à partir de fluides modèles [protéines (O), phosphates (-), lipides $(\triangle)], v=0,096 \mathrm{~m} \cdot \mathrm{s}^{-1} ; 72^{\circ} \mathrm{C}$.

\section{F. Whey "with no calcium precipitable "}

When calcium was complexed by addition of citrate to whey, the XPS analysis of two samples $\left(2.5 \mathrm{~min}\right.$ for $\Delta \mathrm{T}=0{ }^{\circ} \mathrm{C}$ and $10 \mathrm{~min}$ for $\Delta \mathrm{T}=5{ }^{\circ} \mathrm{C}$ with 7 and $15 \mu \mathrm{g} . \mathrm{cm}^{-2}$ masses) revealed the presence of large amounts of $\mathrm{N}, \mathrm{O}$ and $\mathrm{C}$, but no $\mathrm{Ca}$ and $\mathrm{P}$ (table 2). IR spectrometry showed that proteins were present in a large proportion from the beginning of fouling. The amounts of phosphates detected after calcination were very small and their absorbance profile was not characteristic of a calcium phosphate, confirming the above results. The limitation of phosphate growth to the long running times, even more distinct for $\Delta \mathrm{T}=5^{\circ} \mathrm{C}$, seems to confirm the existence of a primary mechanism of adsorption, different from the further growth phase, very limited here and even blocked for $\Delta \mathrm{T}=0^{\circ} \mathrm{C}$. The importance of $v_{\mathrm{s}}\left(\mathrm{COO}^{-}\right)$ (1 $400 \mathrm{~cm}^{-1}$ ) was analogous to that of poorly fouling substances at low temperature (fig. 1) : the $\mathrm{PO}_{4}^{3-}$ base could not precipitate with calcium (too strongly 
complexed), resulting in a local shift of the acid-base equilibrium of carboxylate groups. The relative protein content was larger than in the case of whey (fig. 5.1.) and the phosphates detected at the short running times were probably bound to iron ions at the surface of the passive stainless steel layer.

The test $\left(72{ }^{\circ} \mathrm{C}, \Delta \mathrm{T}=5^{\circ} \mathrm{C} ; 10 \mathrm{~min}\right)$ with whey decalcified by diafiltration (but with a residual calcium content of $9.6 \mathrm{mg} \cdot 1^{-1}$ and no $\alpha$-lactalbumin) led to a deposit mass of $26 \mu \mathrm{g} \cdot \mathrm{cm}^{-2}$, twice larger than that found for whey with calcium complexed by addition of citrate. The spectrum obtained with XPS showed the presence of oxygen, carbon, nitrogen, chromium and iron. Within the sensitivity limits of this method neither calcium nor phosphorus could be detected, which confirmed the results obtained with the previous fluid.

\section{G. Skimmilk}

The infrared spectra showed the same characteristics as for whey, but the relative amplitudes varied less rapidly with time (fig. 5). The carboxylate band towards $1400 \mathrm{~cm}^{-1}$ was large and this could be associated with the low fouling ability of milk. The bands of low intensity situated at $2840,1745,600 \mathrm{~cm}^{-1}$ and between $1000-1100 \mathrm{~cm}^{-1}$ were irregular as affected by pollution and thus not characteristic.

The relative variations were low and paradoxically general trends could be stated only for $\Delta \mathrm{T}=0{ }^{\circ} \mathrm{C}$ : increase in the amount of phosphates after long running times at the expense of proteins (fig. 5). The relative proportion of the latter was higher than for whey. The opposite was observed for lipids showing a very large variation range in the case of whey (fig. 4 and 5).

\section{Discussion}

The rapid increase in fouling masses from a temperature of about $60{ }^{\circ} \mathrm{C}$ indeed corresponds to what was observed recently in a plate heat exchanger (RoIGnant et al., 1986). According to Hege (1984), the fouling by soluble protein solutions, by milk inorganic ions and lastly whey and milk as affected by temperature seems to be consistent with the deciding effect of the native $\beta$ lactoglobulin content on the fouling rate. And yet, the precipitation of calcium phosphate observed in our study doubtlessly contributed to film growth at temperatures exceeding $65^{\circ} \mathrm{C}$, resulting in a decrease in the amount of proteins (relative to inorganic salts) with increasing temperature, up to $75^{\circ} \mathrm{C}$.

The adsorption of proteins, especially stimulated at the carboxylate functions, on surface bound $\mathrm{Ca}^{2+}$ ions and their insolubilization from the beginning of their heat denaturation might explain the variations in the relative proportions of proteins and phosphates at low temperatures. Phosphates only played a structural part from a temperature of $60^{\circ} \mathrm{C}$ when the deposition velocity of protein bound amorphous calcium phosphate increased at the surface. At higher temperatures $\left(>75^{\circ} \mathrm{C}\right)$ a further kinetics increase caused a precipitation in the homogeneous medium at the expense of the surface. 
Lipids were present in the whole temperature range $\left(25-88^{\circ} \mathrm{C}\right)$, especially at temperatures below the insolubilization of calcium phosphate. These lipids were probably phospholipids or lipoproteins. The hypothesis of a deposit builtup at $72{ }^{\circ} \mathrm{C}$ from a lipoprotein- $\beta$-lactoglobulin-calcium phosphate complex like that precipitated within the whey fluid in the heat clarification suggested by Fauquant et al. (1985), seems to be most likely.

Fouling kinetics performed with model solutions $\left(72^{\circ} \mathrm{C}\right)$ support these first results obtained with whey.

Thus, the "phosphate + calcium » solution, highly destabilized by preheating, fouled the stainless steel surface with particles of di- and trihydrated $\mathrm{Ca}_{4} \mathrm{H}\left(\mathrm{PO}_{4}\right)_{3}$ hydrogenophosphates. The very weak adhesion of the deposit to the metal carrier showed that the properties of this system only containing inorganic substances were entirely separated from those we were interested in, i.e. whey and milk. The kinetics mentioned above, the insolubilization of a very large amount of calcium phosphate $(75 \%$ of the calcium : table 1$)$ and the quasi absence of the temperature gradient influence (fig. 2) suggested that the particles deposited had previously been precipitated in the fluid.

The presence of citrate in the ultrafiltrate (and whey as well) deeply alter the equilibria between calcium and phosphate ions (BRULE, 1981) so that calcium phosphate precipitation can be inhibited (Termine and Posner, 1970). This was observed both within the fluid and on the stainless steel surface on which the deposit mass was substantially lower than with the previous solution. However, after predominance of organic pollution substances at short running times, an increasing proportion of apatite phase in the process of crystallization appeared (more rapidly in the case of a $5{ }^{\circ} \mathrm{C}$ temperature difference) which was slightly different from the amorphous phosphate reported by DELSING and HidDinK (1983).

According to Heughebaert and Montel (1970), the general formula of amorphous calcium phosphates is :

$$
\mathrm{Ca}_{9} \square\left(\mathrm{HPO}_{4}\right)_{\mathrm{x}}\left(\mathrm{PO}_{4}\right)_{6-\mathrm{x}}(\mathrm{OH})_{\mathrm{x}} \square_{2-\mathrm{x}}(\mathrm{O}<\mathrm{x}<1 ; \square \text { gap })
$$

It evidences the $\mathrm{HPO}_{4}^{-2}$ ion, the conjugated acid of $\mathrm{PO}_{4}^{--}$for Brönsted's couple :

$$
\mathrm{PO}_{4}^{3-}+\mathrm{H}_{2} \mathrm{O} \rightleftharpoons \mathrm{HPO}_{4}^{2-}+\mathrm{OH}^{-}
$$

It is characterized by an absorption at $875 \mathrm{~cm}^{-1}$, which was also found in our spectrum. Increase in the proportion of $\mathrm{HPO}_{4}^{2-}$ (and $\mathrm{OH}^{-}$) after $\mathrm{PO}_{4}^{3-}$ hydrolysis beyond the critical value of $\mathrm{x}=0.5$ results in calcium phosphate crystallization. The appearance of the main bands changes correlatively, i.e. both broad bands of the amorphous phase break-up into two peaks in the better ordered crystalline phase. X-rays confirm this onset of crystallization : six lattice spacings can be detected. This phase does not exclude the interaction with carboxylate groups of citrate ions the presence of which was assumed by McGanN et al. (1983) as well as by Delsing et Hiddink (1983). The analogy with carbonate apatites is obvious. According to VIGNOLLES et al. (1980) the general formula of these phases is :

$$
\mathrm{Ca}_{10-x-y}\left(\mathrm{PO}_{4}\right)_{6-x-y}\left(\mathrm{CO}_{3}\right)_{\mathrm{x}}\left(\mathrm{HPO}_{4}\right)_{\mathrm{y}}(\mathrm{OH})_{2-x-y}
$$


Carboxylate groups may replace carbonates: the corresponding bands are to be observed between 1400 and $1530 \mathrm{~cm}^{-1}$ according to the type of apatite $(\mathrm{A}, \mathrm{B}, \mathrm{AB})$.

Sweet whey is a more heat stable fluid than the ultrafiltrate, giving lower fouling masses at running times exceeding $10 \mathrm{~min}$ and depending on the temperature gradient. According to Hege (1984) this may be explained as follows : the amount of whey proteins is large enough to reduce phosphate crystallization on the surface and conversely crystals occupy a surface unavailable for proteins. As a matter of fact, our IR analyses showed only the beginning of structure organization for calcium phosphate with a shoulder appearing on the main band at $1080 \mathrm{~cm}^{-1}$ (the reverse for an apatite, maximum at $1040 \mathrm{~cm}^{-1}$ ) ; in the far infrared, a maximum was observed around $300 \mathrm{~cm}^{-1}$ instead of a continuous rise of absorption between 400 and $250 \mathrm{~cm}^{-1}$. Thus, it may be concluded that the calcium phosphate observed exhibited a cryptocrystalline structure.

The interpretation of information gathered by IR and XPS involves three main points in terms of fouling mechanism :

- the first layers built-up on the stainless steel surface mainly consist of proteins, confirming the data obtained by DELSING and HIDDINK $(1982,1983)$. On the basis of the work of VAN DuLm et al. (1981), these authors put forward the hypothesis of a coadsorption of small ions such as $\mathrm{Ca}^{+}$, which could be confirmed by the studies of de RHAM and CHANTON (1984) as the precipitation of whey proteins at $95^{\circ} \mathrm{C}$ for 5 min depends on unmasked $\mathrm{Ca}^{2+}$ ions. Although we did not detect calcium at running times below $5 \mathrm{~min}$, our IR analyses show the same trends, but they also indicate that proteins are not the only compounds involved in the first step of fouling. Phosphates and lipids also are present, which might correspond to the lipoprotein - protein calcium phosphate precipitate formed during heat clarification of whey (FAUQUANT et al., 1985). The fact that the proportion of lipids did not increase in the absence of precipitable calcium confirms this hypothesis and it may be concluded that lipids do not play a major part. Besides, in those conditions, very slow fouling kinetics was observed and even twice slower than in the case of whey at short running times, thus confirming the very small amounts of deposit found by Hege (1984). Not insignificant proportions of phosphate of unspecified form were found in these first layers. An interaction with the carboxylate groups of aspartic and glutamic acids of whey proteins is possible as referred to for the ultrafiltrate from the general scheme of VIGNOLLES et al. (1980). These groups might directly complex calcium possibly present on the surfaces (which was not evidenced in this work).

- induction of fouling by whey described by this first mechanism involved an increasing proportion of proteins and a decreasing proportion of phosphates, but after about $10 \mathrm{~min}$, the proportion of phosphates rapidly increased (showing a characteristic band profile) at the expense of that of proteins, both at $72^{\circ} \mathrm{C}$ and $88^{\circ} \mathrm{C}$ and whatever the temperature gradient $\left(0-10^{\circ} \mathrm{C}\right.$ difference) : $\frac{\mathrm{CO} \text { amide }}{\mathrm{PO}}$ and $\frac{\mathrm{NH}}{\mathrm{Ca}}$ ratios decreased. According to Hege (1984),

$37 \%$ calcium phosphate was obtained after $60 \mathrm{~min}$ of fouling by whey at $85^{\circ} \mathrm{C}, \Delta \mathrm{T}=5^{\circ} \mathrm{C}$. This clearly shows that such a type of compound, structurally 
bound to proteins, is one of the main factors of the second phase, i.e. deposit growth ;

- when no precipitable calcium was present, deposit growth was in fact stopped. This finding seems to be well established now, since Delsing and HidDinK (1983) as well as HeGe (1984) in different approaches and experimental conditions as compared to ours, already evidenced this important point. This growth is thus confirmed to depend on the possibility of calcium phosphate precipitation as fouling remains also very low in the absence of phosphate ions (deionized whey + calcium) (DELSING and HIDdink, 1983).

Fouling was less marked with skimmilk than with whey, as mentioned by HeGE (1984) who hardly detected any deposit after $3 \mathrm{~h}$ of heat treatment at $85^{\circ} \mathrm{C}, \Delta \mathrm{T}=5^{\circ} \mathrm{C}$, just as in the case of whey protein solution. The very good stabilization of calcium and phosphates in milk (as linked to the organization of caseins as micelles) does explain why milk is not as foulant as whey, a result that we pointed out during heat treatment test with a pilot exchanger (Roignant et al., 1986). Therefore a discrepancy exists with the findings of DELSING and HIDDINK (1983) who stated that the deposit mass increased with increasing protein content of the fouling fluid (ultrafiltrate, whey, milk).

Many attempts have been made to determine the nature of the components present in milk macrodeposits. For instance, ITo and NAKANISHI (1966, 1967, 1968) found compositions as inorganic salts (mainly $\mathrm{Ca}$ and $\mathrm{P}$ ) and proteins (whey caseins and proteins); LALANDE et al. (1984 a) found 50-60\% proteins, $10-30 \%$ ash and $12-20 \%$ fat in a milk pasteurizer (treatment temperature : $82^{\circ} \mathrm{C}$ ). A multiple regression analysis of the amino acid content gave a calculation for protein distribution : 35-85\% $\beta$-lactoglobulin ; $3-7 \% \alpha-$ lactalbumin ; $5-40 \%$ casein and immunoglobulin ; $12-20 \%$ bovine serum albumin. Among the proteins which are most currently involved in the hypothesis on fouling mechanism, $\beta$-lactoglobulin seems to play a basic part (SKUDDER, 1981 ; LALANDE et al., 1984 b). Indeed, simulating its denaturation kinetics according to HILLIER and LySTER equations (1979) evidences a good agreement between deposit mass profile and denaturation velocity (LALANDE et al., 1984 b). In addition, TISSIER et al. (1985) showed that the proportion of inorganic material decreased with time and increased subsequently. This work confirms such a development (similar to that found with whey but with a much smaller amplitude) and specify the presence of phosphate and calcium in a much less organized structure as was detected in the case of the synthetic ultrafiltrate. On the other hand, Bouman et al. (1982) found in thin or thick deposits a $\mathrm{Ca} / \mathrm{P}$ ratio of 1.5 and merely referred to tricalcium phosphate. For these authors the fact that the $\mathrm{Ca}_{3}\left(\mathrm{PO}_{4}\right)_{2} /$ protein ratio $(2.731 / 1)$ was 30 fold higher than that observed in casein micelles was a further evidence that the deposit did not consit of casein micelles.

According to LALANDE et al. (1984 a), precipitation of inorganic salts is not connected to the temperature gradient. It depends on the other deposit components, especially proteins, supporting the view that part of calcium phosphate comes from these micelles.

As for the first fouling layers (by milk), the study was difficult because of the small amounts of material involved. However, using IR spectrometry, the situation was found to be similar to what was obtained in the case of whey 
with or without precipitable calcium, i.e. a large proportion of proteins and the presence of phosphates and lipids. Proteins and phosphates do not seem to be independent, but only indirect proofs are available ; it was not possible to decide which of them was first present (if any). Two reviews of the litterature made by SANDU and LUnD (1979) and LUND and SANDU (1981) about fouling reactions on heat exchange surfaces do not supply any information about the same question. Bouman et al. (1982) formulated the idea that soluble proteins interact with the metal during the first steps of fouling through reversible structure changes as well as by irreversible denaturation. The adsorption of proteins (non selectively labelled with radioactive iodine) was evidenced by NisBet and LANGDON (1977). These authors noticed that the amounts retained by stainless steel $\left(6.2 \mathrm{~nm}\right.$ thickness, $\left.35^{\circ} \mathrm{C}\right)$ increased with temperature. Correlatively, the adsorption of proteins was much stronger.

Lipids were also detected, but in smaller proportions than with whey. They are often to be found in deposits (apart from phospholipids, KULKARNI et al., 1975) but their part could never be stated as deciding in fouling (BURTON, 1968). According to SANDU and Lund (1979) their presence might be due to interactions with proteins, but this was not evidenced in this study.

All these facts suggest that protein - calcium interactions through carboxylate groups of soluble proteins (aspartate, glutamate) or the phosphate group of casein phosphoserine might play a basic part in the mechanism of milk deposit formation. This scheme might thus be applied to all the fluids used, the building-up of a calcium phosphate phase being possible in the absence of carboxylate groups ("phosphate + calcium» solution) or in their presence (citrate in the ultrafiltrate, whey and milk, soluble proteins and/or caseins in whey and milk). The structure of this calcium phosphate phase was different for the various media.

It is easy to understand why inhibiting calcium phosphate precipitation through a stabilization of phosphate or calcium levels represents an efficient means for preventing fouling. Thus various additions to milk or whey were recently suggested, i.e. citrate and $\mathrm{pH}$ lowering (SKUDDER and BoNSEY, 1985), calcium citrate crystallization germs (DELSING and HiddinK, 1985).

\section{Conclusion}

The present study is a contribution to a better understanding of the fouling mechanism. The latest results of Delsing and Hiddink (1983), Hege (1984), LALANDE et al., (1984 b) made a number of basic points concerning the part of calcium phosphates and proteins more precise, but no general or " unified » scheme was still available from these findings.

By means of infrared spectrometry lipids could be detected from the first instants of fouling both with whey and its derived fluids and with milk. Their relative proportion was low and remained so throughout the experiment. They did not seem to play a deciding part, either in the formation of the first layers or in the deposit growth. 
Such is not the case for calcium phosphates and proteins which were systematically identified from the onset of fouling (except in the case of calcium complexation). Several schemes have been suggested, based in fact on the adsorption of soluble proteins ( $\beta$-lactoglobulin certainly, but perhaps also the highly heat sensitive immunoglobulins) bound to cations $\left(\mathrm{Ca}^{2+}\right)$, to calcium phosphate or even to a calcium phosphate - lipoprotein complex. All data collected in this study suggest for the formation of the first deposit layers a mechanism in which the interaction between proteins, phosphates and calcium seems to be the key element. This interaction might involve the carboxylate groups of aspartic and glutamic acids in proteins and phosphoserine in milk caseins.

As for the deposit growth, it is basically linked to the presence of calcium and phosphate. Indeed, it gets possible only if a calcium phosphate (with various structures according to the media, e.g. citrate, caseins) is susceptible to provide a link with heat denaturated proteins ( $\beta$-lactoglobulin alone or aggregated to $\kappa$-casein of milk micelles). In the absence of proteins, this type of component may induce much thicker, but less adhering fouling. The ability of the fluid to precipitate this type of salt with a « reverse solubility », but also to form stable co-precipitates with the deposits determines the growth of the latter. This conclusion takes into account the basic influence of the temperature gradient on the fouling capacity of fluids. Moreover it emphasizes the part played by calcium complexing substances in the broad sense (phosphates, citrates, soluble proteins, caseins) to fix the fouling capacity of the fluid and the proportion of inorganic compounds in the films. Such a capacity decreases from ultrafiltrate to whey and to milk. Accordingly, any operation aiming at destabilizing calcium phosphate will contribute to reduce fouling.

Reçu le 26 septembre 1986.

Accepté pour publication le 24 décembre 1986.

\section{Acknowledgments}

We are greatly indebted to $P$. STIPON for his contribution to this work during his stay in our laboratory at the end of his studies at E.N.S. Agronomy, Rennes (1984).

The contribution of Kirsten Rerat (Unité Centrale de Documentation, INRA, Jouy-en-Josas, France) for the translation of this paper is gratefully acknowledged.

This work was supported by a Ministère de l'Industrie et de la Recherche 83 C0165 grant.

\section{References}

Amariglio S., Serres L., Petranxienne D., 1973. Contrôle de la qualité des produits laitiers, 1. Analyse physique et chimique. Ed. Direction des services vétérinaires. Laboratoire central de l'inspection du lait.

Aschaffenburg R., DRewry J., 1959. New procedure for the routine determination of the various non casein proteins of milk. Int. Dairy Congr., London, 3, 1631-1637.

Bouman S., Lund D.B., Driessen F.M., Schmidt D.G., 1982. Growth of thermoresistant Streptococci and deposition of milk constituants on plate heat exchangers during long operating times. J. Food Prot., 45, 806-812. 
Brule G., 1981. Les minéraux du lait. Rev, Lait. Fr. (400), 61-65.

Burton H., 1968. Deposits from whole milk in heat treatment plant + a review and discussion. $J$. Dairy Res., 35, 317-330.

Delsing B.M.A., Hiddink J., 1982. Model studies on fouling in an annular tube heat exchanger, XXI Int. Dairy Congr., Moscow, I, 222-223.

Delsing B.M.A., Hiddink J,, 1983. Fouling of heat transfer surfaces by dairy liquids. Neth. Milk Dairy J., 37, 139-148.

de Rham O., Chanton S.S., 1984. Role of ionic environment in insolubilization of whey proteins during heat treatment of whey products. J. Dairy Sci., 67, 939-949.

Fauquant J., Viecó S., Brule G., Maubois J.-L., 1985. Clarification des lactosérums doux par agrégation thermocalcique de la matière grasse résiduelle. Lait, 65, 1-20.

HEge W.U., 1984. Ueber die Bildung von Ablagerungen beim Erhitzen von Milch und Molke. Thesis. University of Technology, Munich.

Heughebaert J.C., Montel G., 1970. Sur l'existence d'une série de solides de composition variable correspondant au phosphate tricalcique précipité. C.R. Acad. Sci. Paris, 270, Sér. C, 104-107.

HidDINK J., 1985. Fouling of a plate heat exchanger by sweet whey and its ultrafiltration permeate. Second International Conference on Fouling and Cleaning in Food Processing, Madison, U.S.A., 14-17 July.

Hillier R.M., Lyster R.L.J., 1979. Whey protein denaturation in heated milk and cheese whey. J. Dairy Res., 46, 95-102.

Ito R., NAKANISHI T., 1966. A study on milk deposit formation on heat exchange surfaces in the UHT systems. XVII Int. Dairy Congr., B, 613-618.

Ito R., NAKanishi T., 1967. Formation of milk deposits on heat exchange surfaces in UHT pasteurizing plants. Jap. J. Dairy Sci., 15, A 78-88.

Ito R., NaKanishi T., 1968. Formation of milk deposits on heat exchange surfaces in UHT pasteurizing plants. Dairy Sci. Abstr., 3669.

Kulkarni S.M., Arnold R.G., Maxcy R.B., 1975. Evaluation of soil deposition and removal processes : an interpretative review. I. Dairy Sci., 58, 1922-1936.

Lalande M., Tissier J.P., Corrieu G., 1984 a. Fouling of heat transfer surfaces related to $\beta$ lactoglobulin denaturation during heat processing of milk. Biotechnol. Prog., 1, 131-138.

Lalande M., Tissier J.P., Corrieu G., 1984 b. Fouling of a plate heat exchanger used in ultra high temperature sterilization of milk. J. Dairy Res., 51, 557-568.

Lund D.B., BixBy D., 1975. Fouling of heat exchange surfaces by milk. Process Biochem., 10, 5255 .

Lund D.B., SANDu C., 1981. State of the art of fouling : heat transfer surfaces. In : Fundamentals and applications of surface phenomena associated with fouling and cleaning in food processing. Ed. Hallstrom B., Lund D.B., Tragardh C., Sweden : Lund University, 25-56.

McGann T.C.A., BuchHeim W., Kearney R.D., Richardson T., 1983. Composition and ultrastructure of calcium phosphate-citrate complexes in bovine milk systems. Biochim. Biophys. Acta, $760,415-420$.

NisBet T.J., LANGDON A.G., 1977. Milk protein interactions at stainless steel/aqueous interfaces. J. Dairy Sci. Technol. 12, 83-87.

OgG C.L., 1960. Determination of nitrogen by the micro-Kjeldhal method. J. Assoc. Off. Agric. Chem., 43, 689-693.

Pierre A., Brule G., Fauquant J., 1983. Etude de la mobilité du calcium dans le lait à l'aide du calcium 45. Lait, 63, 473-489.

Roignant M., Daufin G., Michel F., 1983. Dispositif expérimental pour étudier l'encrassement des échangeurs de chaleur alimentaires. Lait, 63, 363-390.

Roignant M., Daufin G., Michel F., Kerhervé F.-L., Brule G., 1986. Traitement thermique de rétentat (x2) d'ultrafiltration de lait dans un échangeur à plaques: aspects thermiques, hydrodynamiques et encrassement par comparaison au lait et au lactosérum. Lait, 66, (3), 207-232. 
Roignant M., 1987. Etude de l'encrassement des échangeurs de chaleur à plaques lors de traitements thermiques de produits laitiers à des températures inférieures à $100{ }^{\circ} \mathrm{C}$. Thèse Docteur Ingénieur, E.N.S.A. Rennes.

SANDU C., Lund D., 1979. Chemical reaction fouling due to foodstuffs. In : Fouling of heat transfer equipment. Ed. Somerscales E.F.C., KnudSen J.G., U.S.A. : Rennselar Polytechnic Institute Troy-New-York, 437-476.

SKUDDER P.J., 1981. The role of sulfhydryl groups in the formation of proteinaceous deposit from milk on heated surfaces. In : Fundamentals and applications of surface phenomena associated with fouling and cleaning in food processing. Ed. Hallstrom B., Lund D.B., Tragardi C., Sweden : Lund University, 378-387.

SkUdDer P.J., Bonsey A.D., 1985. The effects of milk $\mathrm{pH}$ and citrate concentration on the formation of deposit during UHT. In : Fouling and cleaning in food processing. Ed. LunD D.B., Plett E., Sandu D., U.S.A. : University of Madison-Wisconsin, 226-234.

STIPON P., 1983. L'encrassement des surfaces chauffées par les produits laitiers : tentative d'établissement de relations avec la stabilité thermique des constituants du lait. Rapport bibliographique, E.N.S.A. Rennes.

Termine J.D., Posner A.S., '1970. Calcium phosphate formation in vitro, 1. Factors affecting initial phase separation. Arch. Biochem. Biophys., 140, 307-317.

Tissier J.P., Galeotti M.A., Lalande M., 1985. Experimental and analytical study of milk deposit on heated stainless steel surfaces. In : Fouling and cleaning in food processing. Ed. Lund D.B., Plett C., Sandu C., U.S.A. : University of Madison-Wisconsin, 178-202.

Van Dulm P., Norde W., Lyklema J., 1981. Ion participation in protein adsorption on solid surfaces. J. Colloid Interface Sci., 82, 77-82.

Vignolles M., Faure J., Legros R. Bonel G., Guichard M., 1980. Contribution à l'identification du constituant minéral de quelques calculs salivaires par l'étude de leur comportement thermique. J. Biol. Buccale, 8, 103-115. 